\title{
Immuno-chemiluminescense detection of allergenic proteins from rubber gloves and natural rubber latex \\ Deteksi protein allergen secara imunokimia dari sarung tangan dan lateks karet alam
}

Siswanto*)

Indonesian Research Institute for Biotechnology and Bioindustry, Jl. Taman Kencana No. 1 Bogor 16128, Indonesia

Diterima tanggal 8 April 2015/disetujui tanggal 3 Juni 2015

\begin{abstract}
Abstrak
Lateks alam maupun produk jadi yang berasal dari karet alam diketahui mengandung protein alergen. Namun demikian identifikasi jenis protein allergen belum banyak dilaporkan. Penelitian ini bertujuan untuk mendeteksi protein alergen dari sarung tangan dan lateks karet alam menggunakan metode immuno-chemiluminescense. Protein diekstrak dari tiga fraksi sentrifugasi lateks (serum B, serum $\mathrm{C}$ dan partikel karet) serta tujuh jenis sarung tangan komersial, kemudian dipisahkan berdasarkan berat molekulnya melalui Gel elektroforesis 1-D (SDS PAGE) dan 2-D. Selanjutnya untuk deteksi protein allergen secara immuno-chemiluminescense dilaku-kan imunobloting menggunakan serum Ig_E tiga pasien yang terbukti positif alergi terhadap protein asal sarung tangan lateks, kemudian diwarnai dengan Sypro Ruby protein blot fluorescence. Hasil penelitian menunjukkan bahwa berdasarkan hasil analisis Western blot one-DE sampel protein lateks menggunakan serum tiga orang tenaga medis yang terbukti positif alergi terhadap protein lateks, maka dapat diidentifikasi 14 jenis protein alergen pada sarung tangan lateks, empat diantaranya merupakan pita major yaitu Berat Molekul (BM) 35, 38, 46 dan $56 \mathrm{kDa}$. Protein allergen pada sarung tangan tersebut kemungkinan berasal dari bagian $\mathrm{C}$-serum terutama protein $\mathrm{BM} 46$ dan $56 \mathrm{kDa}$ ataupun campuran antara C-serum dan B-serum dari lateks karet alam. Hal ini dibuktikan bahwa dari sampel C-serum lateks dapat teridentifikasi 12 protein alergen, empat diantaranya merupakan pita major yaitu $\mathrm{BM} 42,46,51$ dan $56 \mathrm{kDa}$. Sedangkan dari sampel B-serum teridentifikasi tiga pita major dengan BM 14, 16 and $51 \mathrm{kDa}$. Hasil analisis Western blot 2-DE ekstrak protein sarung tangan menggunakan serum tiga orang tenaga medis yang terbukti positif alergi terhadap protein lateks, maka dapat diidentifikasi 12 - 13 spot protein alergen dengan $\mathrm{pI}$ at 4.0 to 7.0 dan yang paling dominan adalah dengan BM 23, 35, 38, 42, 45, $46 \mathrm{kDa}$.
\end{abstract}

[Kata kunci: Lateks, karet alam,sarung-tangan lateks, protein allergen, immunochemiluminescense, serum Ig_E]

\begin{abstract}
Natural rubber latex and finished products derived from natural rubber is known to contain allergenic proteins. Nevertheless identification of allergenic protein has not been widely reported. This study aims to detect the protein allergens from the glove of hands and natural rubber latex using immuno-chemiluminescense. Proteins extracted from the latex centrifugation three fractions (serum B, serum $\mathrm{C}$ and rubber particles) as well as seven types of commercial gloves, then separated by molecular weight through 1-D gel electrophoresis (SDS PAGE) and 2-D. Furthermore, for the detection of allergen proteins in immuno-chemiluminescense performed immunoblotting using the serum IgE three patients who tested positive for allergy to latex gloves native protein, and then stained with fluorescence Sypro Ruby protein blot. The results showed that based on the results of Western blot analysis of one-DE latex proteins using serum samples three medical personnels who tested positive for allergy to latex proteins, we can identify 14 types of protein allergens in latex gloves, four of which are major bands that having Molecular Weight (MW) 35, 38, 46 and $56 \mathrm{kDa}$. Protein allergen on the gloves are likely to come from the C-serum protein mainly MW 46 and $56 \mathrm{kDa}$, or a mixture of $\mathrm{C}$-serum and $\mathrm{B}$-serum of natural rubber latex. It was proved that from $\mathrm{C}$-serum samples could be identified as many as 12 protein latex allergens, four of which were major bands that MW 42, 46, 51 and $56 \mathrm{kDa}$. While the B-serum samples identified three major bands with MW 14, 16 and $51 \mathrm{kDa}$. Results of Western blot analysis of 2DE protein extracts glove using the serum three medical personnel who tested positive for allergy to latex proteins, it could be identified 12-13 allergen protein spot with pI at 4.0 to 7.0 and most dominant is the MW 23, 35, 38, 42, 45, 46kDa.
\end{abstract}

[Keywords: Latex, 2-D electrophoresis, natural rubber, latex gloves, immunoblotting, IgG anti-B serum, IgG anti-C serum.]

*) Penulis korespondensi: siswanto99@yahoo.com 


\section{Introduction}

Indonesia is a $2^{\text {nd }}$ rubber producing country in the world, and almost $90 \%$ of rubber gloves produced in Indonesia were exported. The quality of products has to be maintained and meet the requirementsof the international standards from FDA (1997), ASTM (2007) or European Commission (2004) concerning the total protein content in gloves. This issue will not be an easy task for Indonesian glove manufacturers, if a support on advanced research and technology is not provided. Therefore, Indonesia must takes the issue of latex allergy rapidly and seriously, and further research is being carried out on ways to be applied in industries, especially on how to reduce the antigenic and allergenic protein of rubber products, and how to develop the diagnostic kits for latex sensitization and to use as tools for labeling and for detection of protein allergen contents of rubber products from Indonesian manufactures. Eliminating or reducing allergy problems of proteins in natural rubber latex can be done by using chemical method, physical means, or both as in centrifugation to precipitate protein (Rattanaphan, 2012).

Our previous reports demonstrate that the prevalence of latex allergy among 600 healthcare workers who frequently use rubber products, was found to about $5.8 \%$ while among 272 hospital employees who rarely use rubber glove, the prevalence of latex allergy was found only $1.4 \%$. Latex protein allergy (Type I hypersensitivity) has become a significant issue in clinical aspects. Healthcare workers, rubber industry employees, or who have spinabifida and urogenital abnormalities, are at risk for developing this allergy because of the frequent contact to latex materials during repeated operations. The key properties of gloves made of NRL and examines glove barrier and functional characteristics, recent changes in glove technology, developments in NRL allergen measurement methodology have been reviewed by Palosuoet al. (2011).

Quantification of Hev b 1, Hev b 3, Hev b 5 and Hev b 6.02 (allergen proteins) in latex gloves has been reported by Peixinho et al., (2013) and Ratshikhopha et al. ( 2015) by capture enzyme immunoassay (EIA) using commercial kit (FITkit ${ }^{\text {TM }}$, Icosagen, Estonia). FITkit ${ }^{\text {TM }}$ test are based on the use of specific monoclonal antibodies developed against the four major NRL allergen i.e.; Hev b1, Hev b3, Hev b5 and Hev b6.02. Two commercial availability of immunoassay systems i.e., AlaSTAT, and Pharmacia CAP are however designed to measure latex-specific IgE antibodies in human serum.

The most common method to identify latex allergens is to carry out an SDS-PAGE electrophoresis separation of latex proteins then to transfer the separated proteins by Western blotting onto nitrocellulose membrane. The allergenic proteins bands are identified by incubating the membrane with serum of latex-allergic patients to detect $\operatorname{IgE}$ binding. Molecular weights of the proteins can be estimated from their migration on the gel. This study was focused to identify allergenic proteins using onedimensional (one-DE) or two-dimensional (2-DE) gel electrophoresis and immunoblotting of latex proteins with human IgE serum of health care workers sensitive to latex proteins. Allergenic proteins from latex and gloves were detected by immunochemiluminescense detectionusing SYPRO Ruby protein blot stain (Biorad). The fluorescent SYPRO ${ }^{\circledR}$ Ruby protein blot stain provides a rapid, simple and highly sensitive method for detecting proteins on nitrocellulose or polyvinylidenedi-fluoride (PVDF) membranes (blots). For blots of 2-D gels, totalprotein staining makes it easier to localize a protein to a particular spot in the complex protein pattern. The bright, orange-red-fluorescent stain can be easily visualized using UV illumination or a laser scanner (Fereja et al., 2013; Araujo-Filho et al., 2011). SYPRO Ruby stain is fully compatible with colorimetric, fluorogenic and chemiluminescent detection techniques. In contrast, Amido Black, Coomassie Brilliant Blue and colloidal gold stains often block epitopes required for subsequent immuno-detection and the dark color of the stains makes it difficult to visualize colorimetric or fluorogenicimmuno detection reagents (Fereja et al., 2013; Araujo-Filho et al., 2011). The present work describes the profile of allergenic proteins of $\mathrm{C}$ serum, B-serum and rubber particle samples from fresh latex, latex concentrated and extracts of gloves with immuno-chemiluminescense detection after one-dimensional or two-dimensional gel electrophoresis.

\section{Material \& Methods}

\section{Samples preparation}

Latex fractionation was carried out using a high speed centrifugation, while proteins of gloves were extracted in phosphate buffer saline (PBS) pH 7.2 at $37^{0} \mathrm{C}$ for 3 hours. Fresh latex from AVROS 2037 clone or mix clones was centrifuged at $25.000 \mathrm{~g}$ for $45 \mathrm{~min}$, at $4^{\circ} \mathrm{C}$ in a high-speed SORVAL RC 5B. The main fractions obtained are composed of rubber particles (upper phase), cytosolic serum or C-serum (middle phase) and lutoids (bottom fractions). The preparation of extract proteins from B-serum, rubber particles and latex gloves are the same as reported by Siswanto, (2012).

\section{TCA precipitation}

In order to concentrate the protein especially in glove sample prior to electrophoresis, extracts were precipitated by TCA. The precipitation step was performed on $1.5 \mathrm{~mL}$ eppendorf tube. Nine volumes of sample of known protein content were added with one volume of TCA $100 \%$, and then incubate for $15-30 \mathrm{~min}$ on ice at $4^{\circ} \mathrm{C}$. After centrifugation at 
$13,000 \mathrm{rpm}, 4^{0} \mathrm{C}$ for $15 \mathrm{~min}$, the supernatant was discarded, and protein pellet was resuspended in $1 \mathrm{~mL}$ of cold acetone. The samples were centrifuged again at $13,000 \mathrm{rpm}, 5 \mathrm{~min}, 4^{0} \mathrm{C}$, the supernatant was discarded and the precipitated proteins were airdried. The dry pellet in each tube was solubilized by addition with $6.3 \mu \mathrm{L}$ SDS $1 \%+1.25 \mu \mathrm{L}$ DTT $1 \mathrm{M}$ and $\pm 55 \mu \mathrm{L}$ rehydration buffer to make a volume total $125 \mu \mathrm{L}$. If necessary, thermoshaker for $30 \mathrm{~min}$ to $2 \mathrm{~h}$ until the solution is dissolved and clear.

\section{Human IgE sera}

Blood sera was obtained from three latex-allergic healthcare workers who previously positive on skinprick tested (SPT) with latex standard (Stallergen). One negative serum was obtained from laboratory technician who have SPT test negative to latex standard but has the occurrence allergic to certain fish, foods and some antibiotics. Blood samples were collected in sterile plastic tube and incubate at room temperature for 30-60 min to coagulate, and then incubate at $4^{\circ} \mathrm{C}$ overnight to allow the clot to contract. The serum was decanted away from the clot into a new centrifuge tube, and spin at 3,000 RPM for $10 \mathrm{~min}$ to remove the remaining clots/red blood cells and other insoluble material. Some aliquots were made and add 5-10 mM sodium azide to keep bacteria from growing in it and then store at $-80^{\circ}$ until used.

One-dimensional (one-DE) and Two-dimensional (2$D E)$ gel electrophoresis

Latex proteins were separated by One-DE and 2DE as reporter earlier (Siswanto, 2012). The second dimension was run on a Mini Protean II Cell (Biorad) by place the IPG gel strip on top of a $12 \%$ stacking gel acrylamide SDS-PAGE. The IPG strip was carefully press with a spatula onto the surface of the SDS gel to achieve complete contact. The standard protein was applied in the right side of gel, then the strip was overlaid with hot agarose $0.5 \%$ in buffer equilibration. After allowed the agarose to solidify for $5 \mathrm{~min}$, then electrophoresis was run at 110 volts, $90 \mathrm{~mA}, 9$ watt for about $\pm 1.5-2 \mathrm{~h}$.

\section{Protein gel and PVDF membranes staining}

Protein was stained withCoomassie blue or silver gel staining, and SYPRO Ruby protein blot stain (Biorad 170-3127) after electroblotting proteins to a PVDF membrane as explains in our previous report (Siswanto, 2012).

\section{Immunoblotting for detection allergenic proteins from latex}

The procedure for immunoblotting of latex protein is the same as described in our previous report (Siswanto, 2012). After separation proteins in One-DE or 2-DE, then transferred onto nitrocellulose or PVDF membranes to detect the binding pattern with Human-IgE against protein latex. The $1^{\text {st }}$ antibody used was three sera of latex-allergic patients individually after diluted 1: 6 in western buffer containing $5 \%(\mathrm{w} / \mathrm{v})$ nonfat dry milk, and incubation was done in a minimum volume with a heat sealed bag. And the $2^{\text {nd }}$ antibody used was peroxidaseconjugated goat anti-human IgE (Sigma A 9667) diluted 1: 1000 in western buffer containing 5\% (w/v) nonfat dry milk. The membrane was washed again in western buffer for $30 \mathrm{~min}$, then detecting the chemiluminescence in LAS-1000 after incubating in $5 \mathrm{~mL}$ of Supersignal west dura extended duration substrate, Pierce-Perbio for one min according to the manufacture instruction to generate the chemiluminescence reaction product. Those polypeptides which bound to the Human IgE from latex-allergic healthcare workers were classified as allergenic latex proteins.

\section{Results and Discussion}

For detection of allergenic proteins, the sample used in one-DE mini gel was about $100 \mu \mathrm{g}$ protein/ well and in 2-DE was about 250 to $500 \mu \mathrm{g}$ protein/ gel, then immunoblot detection with human IgE sera at dilution 1:6 (v/v). In all of the immunoblot assays, the concentration of secondary antibody used i.e., peroxidase-conjugated goat anti-human $\operatorname{IgE}$ for detection of allergenic proteins which was diluted $1: 1000$. Although in the product manual suggested to use the dilution of $2^{\text {nd }}$ antibody at $1: 10,000$, trying to use this antibody more diluted (1: 5000) for allergenic protein detection result no signal (data not shown), however after reincubate with the concentration of 1: 1000 we found a good signal of chemiluminescence. This means that not only the $1^{\text {st }}$ antibody but also the $2^{\text {nd }}$ antibody concentrations are determinants for immunoblot detection.

\section{Western blot in one-dimensional gel electrophoresis} for allergenic determinants

The results of IgE-binding pattern of C-serum, Bserum, latex concentrated and gloves samples with each of individual serum from three positives sera of latex-allergic healthcare workers was shown in Figure $1 \mathrm{~A}, \mathrm{~B}$ and $\mathrm{C}$, and also with one serum which negative to latex proteins but has the occurrence allergic to certain fish, foods and some antibiotics (Figure 3 D). Those proteins that bound to the human IgE sera were classified as allergen. Serum from latex positive patients showed identical immunereactivity against each of the $\mathrm{C}$-serum, $\mathrm{B}$-serum and glove proteins. In $\mathrm{C}$-serum extracts, at least twelve immunoreactive bands were observed with the major bands at 42, 46, 51 and $56 \mathrm{kDa}$ and some faint bands at $14,16,21,24.5,30,35,38,40 \mathrm{kDa}$. The $\operatorname{IgE}$ binding pattern of B-serum was less intense than $\mathrm{C}$ serum. In B-serum, only three bands at 14, 16 and $51 \mathrm{kDa}$ were strongly immunoreactive especially in serum $\mathrm{E}(\mathrm{C}+)$ and some diffuse bands were 
detected at approximately $21,26,30,36,38,40$, and $46 \mathrm{kDa}$. In latex concentrate extracts, we found some diffuse immunoreactive bands with only two distinct bands at 51 and $56 \mathrm{kDa}$. Interestingly we found about fourteen immunoreactive bands in the glove extracts. The polypeptides at 35, 38, 46 and 56 were strongly recognized by three IgE positive sera and an addition at $14 \mathrm{kDa}$ only detected with serum E. Some diffuse bands were also observed in glove extracts at 14, 16, $21,24,30,33,42,48,50$ and $51 \mathrm{kDa}$. However, Immunoblot with negative serum to latex also strongly recognize at $42,46,51$ and $56 \mathrm{kDa}$ in Cserum, only one band at $16 \mathrm{kDa}$ in $\mathrm{B}$-serum and faintly detected bands at 35 and $38 \mathrm{kDa}$ in gloves. It must be noted that this patient with skin prick tested negative to latex but has the occurrence allergic to certain fish, foods and some antibiotics. The cross reactivity of latex allergy with foods is well known such as avocado, banana, chestnut, kiwi, papaya, potato, and peaches and it has been reviewed in literatures. There are similarities between the reactivity of the antigenic proteins were detected using rabbit $\mathrm{IgG}$ serum (Siswanto, 2012) with allergen proteins were detected using serum $\operatorname{IgE}$ positive patients allergic to natural latex protein extract. Latex gloves are manufactured using raw materials of concentrated latex. Therefore, the proteins allergens content of concentrated latex should be higher than on the final product of gloves. The low protein content of latex allergens in concentrated than in glove possibility because the present of high ammonia as preservative in concentrated latex disrupt the protein migration during SDS-PAGE electrophoresis and 2-DE.

Western blot in two-dimensional gel electrophoresis for allergenic determinants

Immunoblotting with Human-IgE sera was performed to assess the allergenicity of glove proteins observed in silver-stained two-dimensional gels electrophoresis. 2-DE immunoblot of glove extracts with three IgE positive sera from health care workers revealed some number of polypeptide ranges from 18 to $56 \mathrm{kDa}$ with $\mathrm{pI}$ at 4.0 to 7.0. The number and intensity of spots in serum $S$ and serum $Y$ are relatively similar (Figure $2 \mathrm{~A} \& \mathrm{~B}$ ). and much higher than in serum $\mathrm{E}$ (Figure $2 \mathrm{C}$ ). We found about twelve to thirteen $\mathrm{IgE}$ binding polypeptides indicated by spots no. 1 to 13 in serum $\mathrm{S}$ and $\mathrm{Y}$ and only about 4 spots in serum $\mathrm{E}$ corresponds with spots no. 1,2, 5 and 8 . The strong binding pattern of IgE antibodies were founds at five protein spots at MW $38 \mathrm{kDa}$ and pI at 5.5 to 7.5 (spots no. 4 to 8 ) and two spots at 42 $\mathrm{kDa}$ (spots no. 1 \& 2). Other spots recognized strongly by IgE serum are spot no. 10 at MW 23 (pI 5.0 - 5.3) which probably is Hev b 3, spots no. 9, 1 \& 2 at MW 35, 45, $46 \mathrm{kDa}$ and three diffuse polypeptides at 18, 24 and $51 \mathrm{kDa}$ (spots no.11, 12 and 13).

Human $\operatorname{IgE}$

(A)+

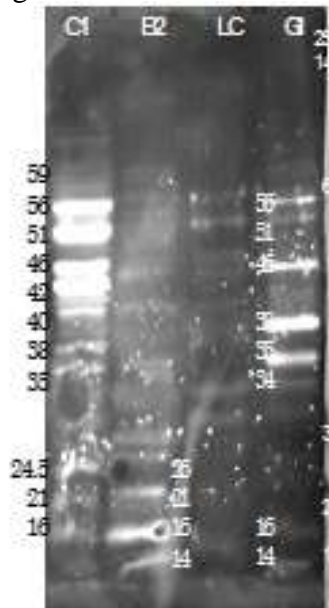

(B)+

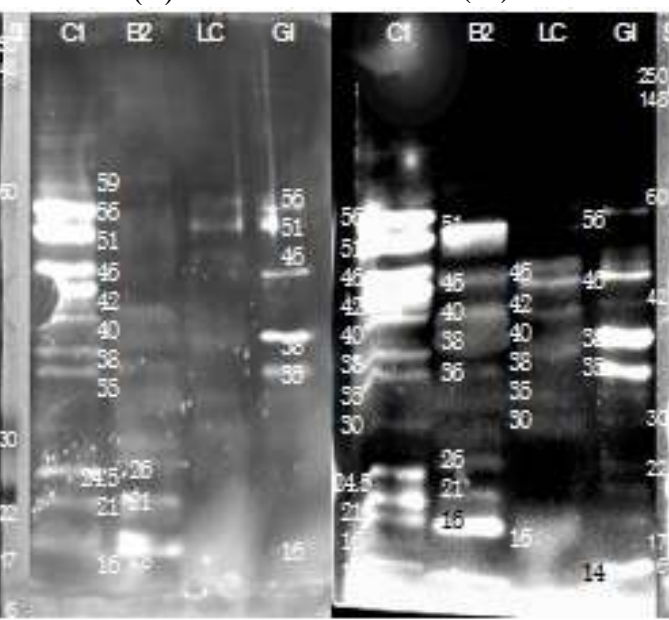

(D)-

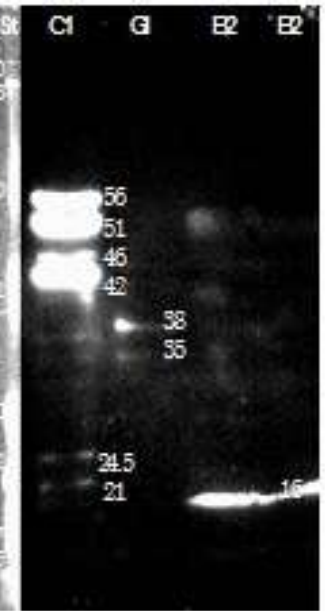

Figure 1. Western blot analysis of latex proteins with three healthcare-workers positive sera: serum $S$ (A), serum Y (B) \& serum E (C) and one negative serum A (D). Latex proteins are C serum (C1), Bserum (B2), latex concentrated (LC) and mixture seven brands of glove extracts (GL), and detection by chemiluminescence using Anti-human IgE peroxidase conjugate at 1:1000.

Gambar 1. Analisis Western blot sampel protein lateks menggunakan serum tiga orang tenaga medis yang terbukti positif alergi terhadap protein lateks, yaitu serum $S(A)$, serum $Y(B)$ \& serum $E(C)$ serta serum $A(D)$ yang berasal dari satu orang yang terbukti negatif. Sampel protein lateks yang digunakan adalah serum-C $(C 1)$, serum- B (B2), serum lateks pekat $(L C)$ dan ekstrak protein dari tujuh merk sarung tangan. Deteksi chemiluminescence menggunakan Anti-human IgE peroxidase conjugate pada 1:1000. 
Excision of protein spots for identification of latex allergen with Mass Spectrometry

In order to achieve the sufficient quantity of protein spots to be used for identification and characterization of latex allergen, we prepared the same separation in 2-DE (pI 3-10) with $200 \mu \mathrm{g}$ of glove proteins after precipitated by TCA and cold acetone. After transfer to PVDF membrane then it was stained with Sypro Ruby (Figure 3 A) and subsequently immunoblotted with IgE serum from the three positive latex allergy health care worker (Figure $3 \mathrm{~B}$ ). We observe some distinct small spots and other diffuse spots in Sypro Ruby staining. Immunoblot with IgE positive serum strongly recognize only four spots i.e., spot no 1 at $24 \mathrm{kDa}$ with pI $4.6-4.8$ (probably Hev b 3), spot no 2 at 38 $\mathrm{kDa}$ with pI 5.6, spot no. 3 at $35 \mathrm{kDa}$ with pI 5.9 and spot no. 4 at $39 \mathrm{kDa}$ with pI 5.4 .

As shown in our previous repot (Siswanto, 2012) the visualization of total proteins by coomassie blue or silver staining in one-DE and 2-DE, the C-serum proteins are therefore numerous probably in the hundreds, but a smaller number of proteins (fewer than 20 major peptides) are founded in B-serum. Various enzymes associated with biosynthesis of rubber are indeed located in the latex C-serum, whereas Hevein is the protein dominant found up $50-70 \%$ of the total B-serum soluble proteins (Jacob et al., 1993).

Our previous research has also study the skin prick test (SPT) to \pm 200 employees of latex industry in Bandung, and 872 hospital employees in Jakarta using latex protein standard (Stallergen). Three healthcare workers known sensitive to latex proteins are further drowning for their $\mathrm{IgE}$ serum collection. These positive sera and one negative serum have been tested individually in one-DE or 2-DE immunoblots to detect the IgE-binding proteins of different latex samples.

Tables 3 summarize the molecular weight of latex allergens founds in C-serum \& B-serum samples in comparison with list of allergens reported by IUIS and predicted some new allergens from latex. In one$\mathrm{DE}$ immunoblot of C-serum sample, all of the latex allergens known before as reported by IUIS were detected. Two allergens Hev b 5 and Hev b 7.01 or $\mathrm{Hev}$ b 13 were founds as major bands, and three allergens identified Hev b 8, Hev b 11 and Hev b 12 were founds as minor bands. However, eight of allergenic proteins at $21,24.5,35,38,40,46,51$ and $56 \mathrm{kDa}$ strongly recognized by the positive sera were probably new allergens which were not yet reported in IUIS list.

In B-serum sample, three major bands identified as Hev b 4, Hev b 6.01, and Hev b 6.03 (at 51, 18 and $14 \mathrm{kDa}$ successively) and two minor bands as Hev b 2 at $36 \mathrm{kDa}$ and $\mathrm{Hev}$ b 10 at $26 \mathrm{kDa}$ were founds in our experiments. $\mathrm{Hev}$ b 6.02 at $4.7 \mathrm{kDa}$ was not found in the B-serum sample, but four minor bands at
$30,38,40$, and $46 \mathrm{kDa}$ were not reported by IUIS. In latex concentrate sample, two distinct bands at 51 and $56 \mathrm{kDa}$ were founds probably represents Hev b 4 originally from B-serum.

As reported also by Yeang et al., (2006) and, in contrast to fresh latex, which contains > $35 \mathrm{IgE}-$ binding polypeptides, finished latex products and gloves appear contain a limited number of allergens. However, interestingly in the glove extracts, we founds fourteen immunoreactive bands, in which four strongly allergenic proteins were probably identified as Hev b 2 at $35 \mathrm{kDa}, \mathrm{Hev}$ b 7.01 at $46 \mathrm{kDa}, \mathrm{Hev}$ b 4 at $56 \mathrm{kDa}, \mathrm{Hev} \mathrm{b} 6.03$ at $14 \mathrm{kDa}$, and unknown allergen at $38 \mathrm{kDa}$. Nine faints bands were also found in glove sample at $16,21,24,30,33,42,48,50$ and $51 \mathrm{kDa}$, some of which were not yet reported in the literatures. Most of these polypeptides were observed in the 6.5 to $50 \mathrm{kD}$ range, which is compatible with the idea that degradation of NRL peptides during the manufacturing process yields smaller proteins. Arguments for the generation of neoantigens on finished latex products have been made by some authors who showed the appearance of new immunoblotting bands in glove extracts compared with fresh latex. This suggests the existence of new epitopes probably on ammoniated latex and glove antigens.

Latex allergens have been also identified by several investigators using 2-DE. Two-dimensional polyacrylamide gel electrophoresis, in which proteins are separated according to charge (pI) in the first dimension and according to molecular weight size $(\mathrm{kDa})$ by SDS-PAGE in the second dimension, has a unique capacity for the resolution of complex mixtures of proteins, permitting the separation of proteins with same molecular weight but different in $\mathrm{pI}$ or vice versa.

Thirteen latex proteins are recognized by the WHO-International Union of Immunological Societies (IUIS) to be allergenic (Table 4). In our study, the strong binding pattern of $\operatorname{IgE}$ antibodies to five protein spots at MW $38 \mathrm{kDa}$ and $\mathrm{pI}$ at 5.5 to 7.5 are our interest in view of searching the new allergenic protein of latex. The major allergen at $38 \mathrm{kDa}$ as seen in one-dimensional gel electrophoresis was in fact represent five protein spots in 2DE. Among ten allergenic proteins reported by IUIS, only one protein at MW $38 \mathrm{kDa}$ but with pI 9.5 to 9.8 was identified as Hev b 2 ( $\beta-1,3$-glucanase), suggesting that five allergenic proteins at MW 38 $\mathrm{kDa}$ found in glove sample were probably a new allergen found in latex. We also found two spots recognized strongly by $\operatorname{IgE}$ serum having the same molecular weight at $\pm 42 \mathrm{kDa}$ with $\mathrm{pI} 5.6-5.8$. This result also clearly demonstrates that one-DE analysis of allergen is not satisfactory to characterize the individual specificity of the IgE binding pattern to latex allergen. The 2-DE of IgE immunoblot will provide valuable information to isolate the relevant latex allergens. 


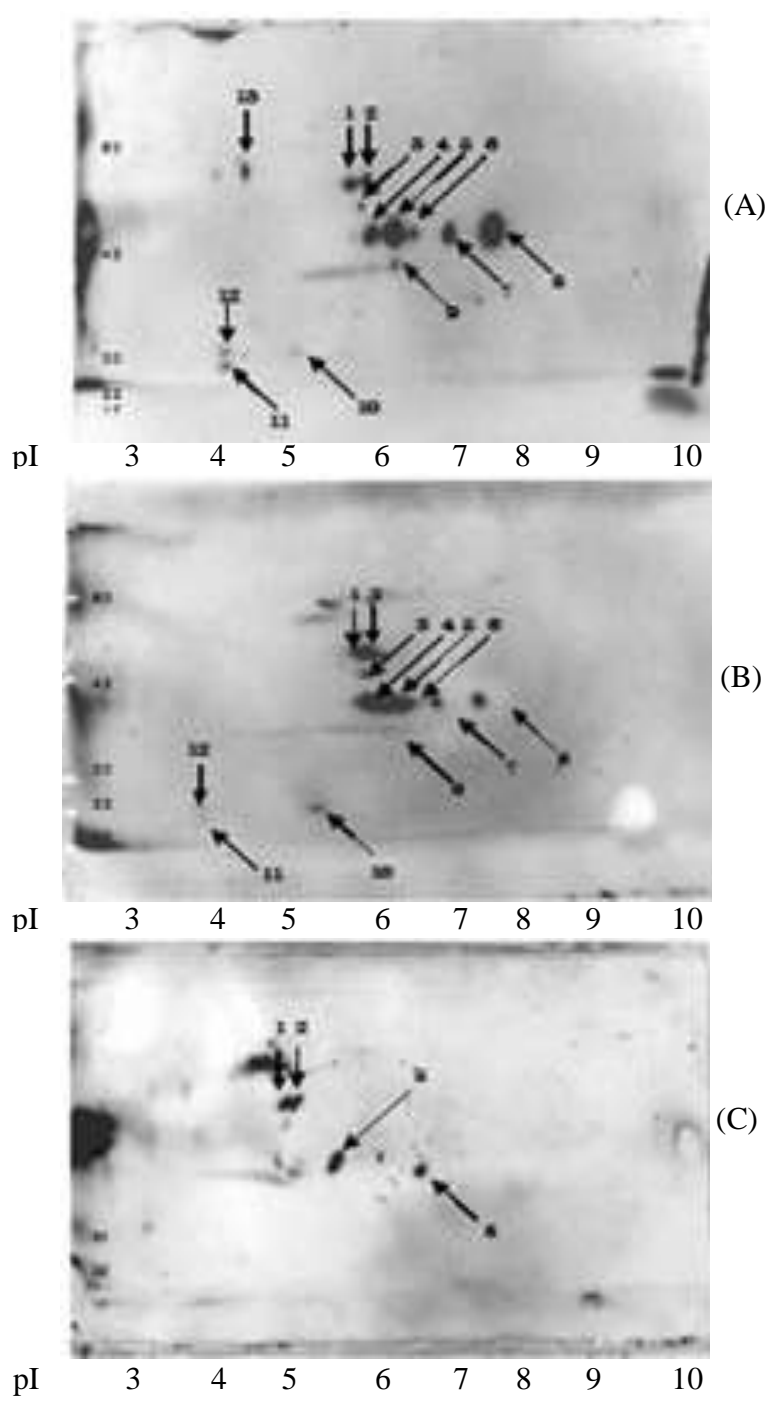

Figure 2. Reactivity on 2-D immunoblotting of the glove proteins with individual three health care workers $\operatorname{IgE}$ positive sera against latex proteins: serum S (A), serum Y (B) and serum E (C).

Gambar 2. Reaktivitas pada 2-D immunobloting dari protein ekstrak sarung tangan dengan tiga serum IgE tenaga medis yang positif alergi terhadap protein lateks: serum $S(A)$, serum $Y(B)$ dan serum $E(C)$

Because latex is processed from its natural form, it is possible that new antigens (neo-antigens) could be formed during the processing. Some investigators have detected an allergen in an extract from gloves that was not present in raw natural rubber latex. Unfortunately, as manufacturing processes change, allergens isolated from finished latex products also change, and therefore are not consistent, reliable sources of latex allergen for testing patients. Many investigators have found that raw natural rubber latex, which is collected without ammonia, is the most consistent source of relevant latex allergens. Additives may constitute another source of allergens in manufactured products. In one instance, casein, a protein added during latex processing, was reported as the cause of glove allergy. However each individual spot on the 2-DE immunoblot does not necessarily represent a distinct protein, since some spots of similar MW may represent isoelectric variants of the same protein. Similarly, spots of different MW may represent fragments or aggregates of single allergen. Therefore this work needs to be continued for identification and characterization of allergenic proteins found in glove extracts, latex concentrate or fresh latex. Coomassie blue stained spots excised from the electrophoresis gel or the blotting membrane can be subjected directly, or after cleavage, to Edman degradation using a gas phase amino acid sequence analyzer, amino acid composition analysis, or mass spectrometry (Gorg, 1998).

In one-DE or 2-DE immunoblot, some immunereactive bands were recognized by $\operatorname{IgE}$ negative serum which indicated that this patient contained $\operatorname{IgE}$ which could be induced by other allergens and could 
Table 3. Latex allergens founds in C-serum \& B-serum samples in comparison with list of allergens reported by WHO-IUIS (International Union of Immunological Societies) (Yeang et al., (2006).

Tabel 3. Latex alergen yang didapatkan dalam sampel serum-C dan serum B dibandingkan dengan daftar alergen yang dilaporkan oleh WHO-IUIS (International Union of Immunological Societies) (Yeang et al., (2006).

\begin{tabular}{|c|c|c|c|c|c|}
\hline \multirow{3}{*}{ Cell localization } & \multirow{3}{*}{$\begin{array}{l}\text { Protein MW } \\
\quad(\mathrm{kDa})\end{array}$} & \multirow{3}{*}{$\mathrm{pI}$} & \multicolumn{3}{|c|}{ Founds in samples } \\
\hline & & & \multicolumn{2}{|c|}{ Reported by IUIS } & \multirow{3}{*}{$\begin{array}{c}\text { Not reported by } \\
\text { IUIS }\end{array}$} \\
\hline & & & MW (kDa) & $\begin{array}{l}\text { Intensity } \\
\text { of band }\end{array}$ & \\
\hline \multicolumn{5}{|l|}{ C-serum } & \\
\hline Hev b 5 & 16 & - & 16 & Major & Major bands: \\
\hline Hev b 7.01/ Hev b 13 & $43-44$ & $4.4-5$ & 42 & Major & $21,24.5,35,38$, \\
\hline Hev b 8 & $10.2-15.7$ & 4.9 & 14 & Minor & $\begin{array}{c}40,46 \\
51 \text { and } 56 \mathrm{kDa}\end{array}$ \\
\hline Hev b 11 & 29 & $26-27.5$ & 30 & Minor & Minor bands: - \\
\hline Hev b $12 /$ profilin & 15.7 & 9.3 & 14 & Minor & \\
\hline \multicolumn{6}{|l|}{ B-SERUM } \\
\hline Hev b 2 & $34-36$ & $9.5-10$ & 36 & Minor & Major bands: - \\
\hline Hev b 4 & $50-57$ & 4.5 & 51 & Major & \\
\hline Hev b 6.01 & 20 & $5.3-5.6$ & 18 & Major & Minor bands : 30 , \\
\hline Hev b 6.02 & 4.7 & $4.7-4.9$ & - & - & 38 \\
\hline Hev b 6.03 & 14 & $6.0-7.4$ & 14 & Major & 40 , and $46 \mathrm{kDa}$ \\
\hline Hev b 10 & $23,25,45$ & $4.3-5.7$ & 26 & Minor & \\
\hline \multicolumn{6}{|l|}{ Rubber Particles } \\
\hline Hev b 1 & 14.6 & $4.9-5.3$ & & & \\
\hline Hev b 3 & $22-23$ & $4.3-5.7$ & & & \\
\hline Hev b 12/ profilin & 15.7 & 9.3 & & & \\
\hline
\end{tabular}

cross-react with latex proteins. This phenomenon has also been reported by Hasma et al. (1998) using IgE serum from rubber tappers with negative SPT to glove and food. It is well recognized that some latexsensitized patients also experience allergic reactions to food allergens. The most common cross-reactivity has been found between latex and such foods as banana, avocado, chestnut, passion fruit, kiwi fruit, potatoes, and tomatoes, all of which have been found to be antigenically similar to latex. Recent research revealed that several proteins related to the defense mechanisms of plants are responsible for latex allergy and the accompanying cross-reactivity (Yagami, 2002).

\section{Conclusion}

Although most of the proteins of natural rubber latex have been eliminated in the manufacture of concentrated latex or during the production process at the factories, but the proteins residue in the final product of gloves or other latex finished goods can still cause allergic reactions in humans. Human Ig-E anti serum positively allergic to latex proteins can be used to detect protein allergens in gloves or other medical devices derived from natural rubber latex either through Western blot one-DE or 2-DE. Fourteen immunoreactive bands of protein extracts gloves were strongly Recognized by three $\operatorname{IgE}$ positive sera, i.e. polypeptides at $35,38,46$ and 56 and some diffuse bands were detected at MW Also 14, 16, 21, 24, 30, 33, 42, 48, 50 and $51 \mathrm{kDa}$. Protein extracts of gloves is more appropriately used for the manufacture of allergen protein detection kit compared to the protein of the C-serum and B-serum.

\section{Acknowledgements}

This research was supported by DAAD grant in continuation with the $1^{\text {st }}$ DAAD-Fraunhofer Techno preneur Awards in Life Sciences". I would like to express my sincere thanks to Professor Herwig Brunner, Director of Fraunhofer IGB, Director of DAAD for the fellowship. I am very grateful and my warmest thanks to Dr. Steffen Rupp, Dr. Kai Sohn under the direction and guidance during the research, Dr. Anke Burger-Kentischer, Georg Geiger Dipl. Ing., and Doris Finkelmeier for their friendly support and advice concerning this laboratory work.

\section{References}

Araujo-Filho JLS, MR Melo-Junior \& LB Carvalho (2011). Potential application of the chemiluminescent methods in tumoral diseases investigation. Int J Pharma and Bio Sci 2(2), B392 B400.

Fereja TH, A Hymete \& T Gunasekaran (2013). A recent review on chemiluminescence reaction, principle and application on pharmaceutical analysis: Review article. ISRN Spectroscopy. Taken from: http://dx. doi.org/10.1155/2013/230858. 
Palosuo T, I Antoniadou, F Gottrup \& P Phillips (2011). Latex medical gloves: time for a reappraisal. Int Arch Allergy Immunol 156, 234-246. DOI:10.1159/000323892)

Peixinho CM, MF Gabriel, C Caramelo-Nunes, P Tavares-Ratado \& CT Tomaz (2013). Separation of the four most important latex allergens from latex gloves: A potential tool for diagnosis and immunotherapy purposes. Allergologia et Immunopathologia. Taken from : http://dx.doi.org/10.1016/j.aller.2013.03.003

Ratshikhopha ME, TS Singh, D Jones, MF Jeebhay, \& AL Lopata (2015). High concentrations of natural rubber latex allergens in gloves used by laboratory health personnel in South Africa. South African. Med J 105(1), 6p. Taken from: http://dx.doi.org/10.7196/SAMJ.8082
Rattanaphan O, D Danwanichakul \& P Danwanichakul (2012). Reduction of protein content in kim rubber via bot extraction in kim latex ana krom rubber film. $1^{\text {st }}$ Mae FahLuang University International Conference 2012: 7pp.

Siswanto (2012). Two-dimensional gel electrophoresis and immunoblotting for detection of antigenic proteins from natural rubber latex. Menara Perkebunan 80(2), 57 - 87.

Yeang HY, RG Hamilton, DI Bernstein, SAM Arif, KS Chow, YH Loke, M Raulf-Heimsoth, H Breiteneder \& RE Biagini (2006). Allergen concentration in natural rubber latex. Clinical and Experiment Aller 36, 1078-1086. 